The Polish Journal of the Arts and Culture. New Series 9

(1/2019): 27-51 [ARTICLE]

DOI: 10.4467/24506249PJ.19.002.11134

\title{
Local Advaita Vedānta Monastic Tradition in Kerala: Locating, mapping, networking
}

\author{
Olga NowickA
}

\begin{abstract}
The article concerns the hitherto unstudied regional variant of the Advaita Vedānta monasticism of the Nampūtiri tradition in Kerala. The main objective of the paper is to present the spatial distribution of the Advaita Vedānta mațhas (skr. mațha - "monastery") in the state of Kerala (South India). Through the cartographic visualisation, I intend to prove that the monastic tradition in question has, in the past, created a network of intricate ritualistic, economic, social and political interrelations spreading across whole Kerala region. The spatial analysis will allow to evaluate the qualities of the mathas' geographical distribution.
\end{abstract}

Keywords: monasticism, Advaita Vedānta, Śañkara, Nampūtiri brahmins, Kerala, Thrissur

Olga NowICKA indologist, $\mathrm{PhD}$ candidate of the Department of Languages and Cultures of India and South Asia in the Institute of Oriental Studies of Jagiellonian University in Cracow, Poland. Her research interests include the Advaita Vedānta monastic tradition in Kerala and the Advaita Vedānta hagiographic tradition also in Kerala. She is the author of articles such as Conquering the World, Subduing the Minds: Sankara's Digvijaya in the Local Context, "Cracow Indological Studies", Vol. XVIII, 2016 and Vedic Ritualism and Advaita Vedānta Monastic Institutions in Kerala, "Studia Religiologica", vol. 50/2, 2017.

E-MAIL: olga.nowickaoo@gmail.com

The presented article is the outcome of the research project funded by the National Science Centre, Poland. Title of the project: In the Footsteps of Śankara: Local Advaita Vedänta Monastic Tradition in the Topographies of Keralan Hagiographies; project no. 2017/27/N/HS2/oo846; grant scheme: Preludium 14. 


\section{Introduction}

The purpose of this paper is to discuss the topic of the hitherto unstudied regional Advaita Vedānta monasticism ${ }^{1}$ of Nampūtiri brahmins in Kerala (South India) ${ }^{2}$. My primary objective in the article is to recognise and locate this local tradition on the map of South India. While we have a number of studies concerning such famous monastic centres, aspiring to the title of "thrones of knowledge" (skr. vidyāpițhas), as Govardhana, Sārada, Dvāraka, Jyotirmaṭha and Kāmakoṭi Pīṭha, there is hardly any concerned with a lesser known place like Thrissur (mal. Tṛśsuurr) ${ }^{3}$ in central Kerala (mal. Kēralam), which constitutes an independent regional variant of the Advaita Vedānta monasticism. The origin of the Keralan Advaita Vedānta monastic tradition is associated with Śankara, and narrated in the local accounts of the philosopher's life. This local literary tradition contrasts with the broadly known, canonical hagiographic tradition of Sankara, which states that during "the conquest of the quarters" (skr. digvijaya), the philosopher reached four corners of the Indian Peninsula, where he established four monastic centres (skr. mațha - "monastery") to propagate the Advaita Vedānta doctrine. These were Govardhana (on the East), Sārada (on the South), Dvāraka (in the West) and Jyotirmatha Pìtha (on the North) ${ }^{4}$. Whereas, according to the local accounts

${ }^{1}$ This monastic order is directly associated with the great Indian philosopher - Sankara. Śankara was a propagator of the non-dualistic doctrine of Advaita Vedānta. He lived most probably ca. $788-820$ and was born in Kalady (mal. Kālați, Kerala, South India). Śankara is considered to be a founder of the pan-Indian monastic order within the Advaita Vedānta doctrine - called Daśanāmī-Sampradāya (skr. daśanāmī - "he who has [one of the] ten names", sampradāya - "tradition"). After initiation into this order, an ascetic is given a new name one of the ten names. H. Kulke, D. Rothermund, A History of India, pp. 141-142.

${ }^{2}$ It needs to be highlighted that my study concerns the Advaita Vedānta monastic tradition in Kerala but only within one particular local community, i.e. within the community of Nampūtiri brahmins.

3 The geographic naming, including the names of the cities and villages, is a problematic issue in the landscape of Kerala due to its complex past and different foreign influences which were present there across the centuries. Thus, what we witness is a kind of historic palimpsest - the geographic Malayalam (malayālam) names are influenced by such languages as Tamil, Portuguese, Dutch and English. The modern maps (modelled on English maps) apply usually the simplified description in Latin script, with English name forms. Because of the broad use of maps in this paper I will use the English name forms with Malayalam forms in the in brackets when first mentioned.

${ }^{4}$ V. Sundaresan, Conflicting Hagiographies and History: The Place of Sankaravijaya Texts in Advaita Tradition, p. 110. 
from Kerala, Śankara founded all four mațas (monasteries) ${ }^{5}$ in one city only - i.e. in Thrissur ${ }^{6}$. The established institutions were the: Northern Monastery (mal. Vatakke Matham), Middle Monastery (mal. Națuvil Matham), In-between Monastery (mal. Ițayil Matham) and Southern Monastery (mal. Tekkē Matham). Subsequently, the philosopher allegedly achieved videha$\tilde{n} k t i$ (liberation after death) in the Śaiva Vatakkunnāthan Temple, located near to the Thrissur monasteries. As the heads of the monastic institutions in Thrissur, Śankara was said to appoint his four main disciples (Sureśvara, Padmapāda, Hastāmalaka, Toțaka) ${ }^{7}$, who afterwards passed mațhas in charge to the community of Nampūtiri brahmins.

Three monasteries have survived in Thrissur until today, while one was relocated outside the city (Ițayil Maṭham). Națuvil and Tekkē Maṭham are still active monastic centres. Vatakke Matham was transformed into a school around the time of the $17^{\text {th }}$ century, where Vedas are taught in a traditional system (skr. vedapāthaśāla a), as it is claimed by the Nampūtiri brahmins in charge of the institution. What is peculiar about the monastic tradition in question, is the prescription according to which the mathas were supposed to be intended only for Nampūtiri brahmins ${ }^{8}$. Furthermore, the embracing of the samnyāsa ("renunciation of the world") there, is possible only for Nampūtiris from a few specific families - i.e. from Sukapuram, Peruvanam and Iriññālakkuṭa grāma ("village"), as I was informed by the current Natuvil Maṭham Svāmiyār at the time of my visit (2018) - Maravancērry Tekkētattu Nīlakaṇthan Bhāratīkal`9

The historic circumstances for the rise of four Advaita Vedānta monastic centres in Thrissur remain still unrecognised and dating uncertain. Due to no veritable historic data, legends still remains in circulation, which when

5 Institution of a mața in the Keralan context is discussed by Cezary Galewicz in: C. Galewicz, Żyjace Biblioteki Indii. Rygweda braminów Nambudiri, pp. 73-74.

6 An alternative variant of this legend circulates in Kerala - it relates that Śankara's disciples founded four monasteries in Thrissur.

7 The first Svāmiyār (head of a mațha) in the paramparā of the Vațakke Mațam (from Malayalam: "Northern Mațha") was said to be Toțaka, of the Națuvil Maṭham ("Middle Maṭha") Sureśvara, of the Tekkē Maṭham ("Southern Maṭha") Padmapāda and of the Ițayil Maṭham ("In-between Mațha") Hastāmalaka.

8 As claim Nampūtiris linked with those institutions.

9 To this peculiar custom refers one normative text of the Keralan Advaita Vedānta monastic tradition - Sanyāsakalpam (first folio, manuscripts M79, M91, 184 available in Vatakke Maṭham Brahmasvam Vedic Research Centre, Thrissur). Text is unpublished, remains only in the form of a palm-leaf manuscript. Manuscript consulted by the author. 
persistently repeated, obscure history. Thus, following the popular accounts, the establishment of those institutions is ascribed to Sankara and the dating estimated for the 9th century. However, it seems rather doubtful that those centres trace their origin so far in the past, as claim historians Prof. M. G. S. Narayanan and Prof. Kesavan Veluthat (in personal communication).

\section{Locating, mapping, networking}

In the most of Sankara's hagiographies, philosophers' pilgrimages are a dominant topos of the narrative. Following the canonical accounts of philosopher's life, during a journey throughout the whole of India, Sankara was said to travel along with his disciples to the four corners of the Indian Peninsula and to defeat doctrinal opponents representing other schools of thought in philosophical disputes ${ }^{10}$. During his triumphant tour (skr. dig-vijaya "conquest of the [four] quarters") he was said to establish four vidyāpithas ("seats of learning"), meant for propagation of the Advaita Vedānta doctrine, each affiliated with one dhäman (skr. dhäman - "seat of the gods", "sacred place of pilgrimage" $)^{11}$.

Similarly, the predominant theme of the local hagiographies of Sankara, originating in Kerala, are the philosopher's peregrinations, i.e. his movement through space, through space where he leaves traces. And thus, according to the local literary tradition, Śankara's pilgrimages culminate in establishing four main vidyāpithas in the city of Thrissur. Regional accounts of philosopher's life transpose the ideological concept of the pan-Indian triumphant tour from macrospace (Indian Peninsula) into microspace, i.e. the region of Kerala. Therefore the basic tool to examine the regional Advaita Vedānta monastic tradition, imprinted in the topographies of Keralan hagiographies, appears to be the map. Thus, while discussing the Nampūtiri Advaita Vedānta monasticism, primarily we need to precisely locate it on the map of Kerala.

\footnotetext{
${ }^{10}$ W. R. Antarkar, Śankara-Vijayas. A Comparative and a Critical Study. Appendix, p. 103.

${ }^{11}$ W. S. Sax, Conquering the Quarters: Religion and Politics in Hinduism, p. 47.
} 


\section{Thrissur and four vernacular mathas}

The city of Thrissur (mal. Tṛsśsur) is located in central Kerala, in the Thrissur Disctrict (it is the headquarter of the district), ca. 20 kilometres east in a straight line - off the shore of the Arabian Sea, and west of the mountain range of Western Ghats ${ }^{12}$. The city is situated ca. 300 kilometres southeast of Kasaragod (mal. Kāsargōd), ca. 210 kilometres south-east of Kannur (mal. Kaṇūur), ca. 120 kilometres south-east of Kozhikode (mal. Kōlikkōṭu), ca. 85 kilometres north of Kochi (mal. Kocci), ca. 130 kilometres north-west of Kottayam (mal. Kōtṭayam) and 280 kilometres north-west of Thiruvananthapuram (mal. Tiruvanantapuram)- the capital of the state ${ }^{13}$. Noteworthy is the spatial organisation of the city - it is built around the hillock which seats the complex of the important śaiva religious center - Vatakkunnāthan Temple ${ }^{14}$.

KERALA

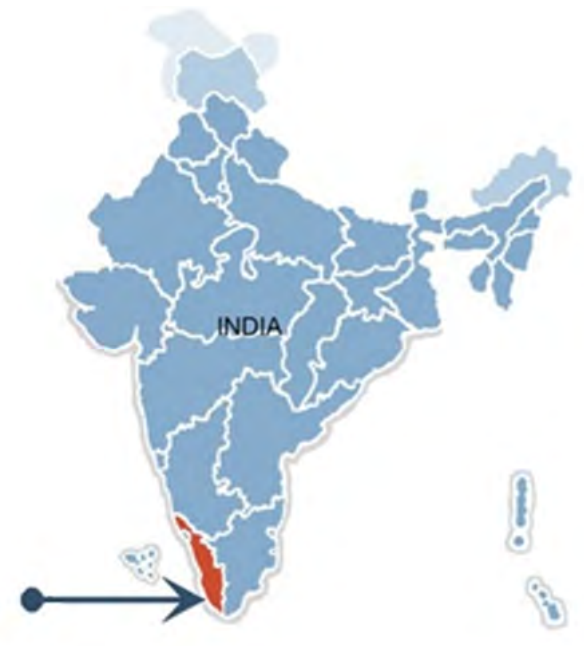

Map 1: Location of Kerala on the map of India (commons.wikimedia.org)

\footnotetext{
${ }^{12}$ A. S. Menon, Kerala District Gazetteers: Trichur, 1962.

${ }^{13}$ Google Earth, [www 01] (access: 28.01.2019).

${ }^{14}$ There are six inscriptions in the Vatakkunnāthan Temple belonging to the 11th and 12th centuries. They refer either to the foundation of structures or about the implementation of certain rules and regulations. The city finds earliest reference in them as "Tiruśivapērūr". Thus inscriptional data points only to the 11 th century $\mathrm{CE}$ as the possible beginning of the temple - notes Prof. T. R. Venugopalan from Thrissur in personal communication.
} 
The shrine thus marks the centre of the town. Around the temple, outside its bordering walls, there is an open space which is said to have been, in the past, a teak forest - hence comes its name Tēkkinkāṭu (from mal. "teak forest") ${ }^{15}$. The hill is nowadays surrounded by a concrete traffic circle - Svarāj Round - from where other roads diverge in all directions ${ }^{16}$.

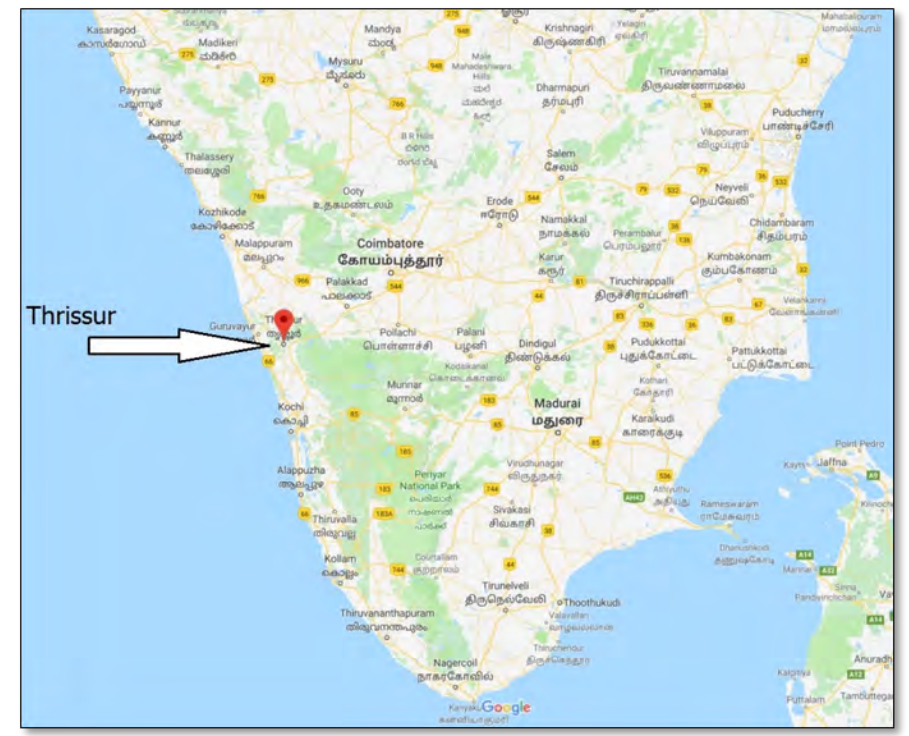

Map 2: Location of Thrissur city in Kerala (map by the author based on Google Maps)

Just less than five hundred meters away from the Vațakkunnāthan Temple, three Advaita Vedānta mațhas - allegedly established by Śankara - are located ${ }^{17}$. According to the regional hagiographic tradition of Sankara, the philosopher is believed to have founded all four Advaita monasteries in the city of Thrissur only. These were, as previously mentioned, the Northern Monastery (Vațakke Maṭham), Middle Monastery (Națuvil Mațham),

${ }_{15}$ For developments in the city of Thrissur such as clearing the ground around the Vatakkunnāthan Temple from a teak forest, renovation of the Vatakkunnāthan Temple, initiating the famous Purram Festival held annually at this temple until today, laying the roads around the temple - Rājā Rāma Varma popularly known as Saktan Tampurān is credited (reign: 1790-1805). A. Achyuthan, T. S. Prabhu Balagopal, An Architectural Guide of Thrissur, pp. 4-5.

${ }^{16}$ A. Achyuthan, T. S. Prabhu Balagopal, op. cit., p. 1.

${ }^{17}$ Measurements conducted through the platform Google Earth: [www 01] (access 29.01.2019). 
In-between Monastery (Ițayil Maṭham) and Southern Monastery (Tekkē Matham). Subsequently, the philosopher is believed to have achieved samädhi (liberation after death) in the nearby Saiva Vatakkunnāthan Temple. In the complex of śaiva Vațakkunnāthan Temple, one can find an erected stone platform commemorating Śankara's samādhi. The undated Śankkara's platform bears two attributes: śankkha ("conch-shell") and cakra ("discus") - noteworthy, these are in fact typical attributes of Viṣnu in Hindu iconography ${ }^{18}$.

Till today, three mathas remain in Thrissur: Vaṭakke Mațam ("Northern Monastery"), Națuvil Mațham ("Middle Monastery") and Tekkē Maṭham ("Southern Monastery") 19. Vatakke Matham functions nowadays as the vedapāthaśāla run by Nampūtiri brahmins (school where Vedas are taught in a traditional system) and is known under the name Vațakke Maṭam Brahmasvam (often shortened to Brahmasvam Maṭam; skr. brahmasva - "property of brahmins"). Națvil and Tekkē Mațhams are still active Nampūtiri Advaita Vedānta monastic institutions.

The map below shows the spatial arrangement of the monasteries and their location in relation to Vatakkunnāthan Temple. The mațas are built in a peculiar line of order which is determined by its names. Vatakke Matham ("Northern Monastery", currently Brahmasvam Matham) is situated in the north, Tekkē Matham ("Southern Monastery") is situated in the south, and Natuvil Matham ("Middle Monastery) is located in the middle of those two mathas. This orientation agrees with the cardinal directions. Mathas are built on the bank of Patịñ̃āru Cira ("Western Pond") ${ }^{20}$.

${ }_{18}$ There is one particular feature which differentiates the Keralan Advaita Vedānta monastic tradition of Nampūtiri brahmins from the pan-Indian Daśanāmī Sampradāya - its religious orientation. Nampūtiri saṃnyāsins are all declared vaiṣnavas, while the pan-Indian tradition of Daśanāmī-Samnyāsins is rather of śaiva orientation. As I have observed during my fieldwork, pūja-mūrtis ("worship idols") in all mathas of Keralan Advaita renunciant tradition are the avatāras (skr. avatāra - incarnation) of the god Viṣnu. Moreover, one of the Keralan Śankkara hagiographies - Śankkarācāryacarita by Govindanātha, roughly dated to ca. 17th century, composed in Sanskrit - in its final passage features Śankara to attain paramānanda in the Vațakkunnāthan Temple (from skr. "supreme felicity", "Supreme Spirit", "soul of the universe") only after composing there a hymn in praise of Viṣnu: deśikendro mahāyogī stotram kurvan sa vaiṣnavam | viveśa paramānandạ̣ bhānubimbāntarasthitam || 9.64.||. W. R. Antarkar (ed.), Śan்karācāryacarita (Govindanātha), [in:] "Bharatiya Vidya" 52 $(1-4)$, p. 136.

${ }^{19}$ The $p \bar{u} j \bar{a}-m \bar{u} r t i s$ of the monasteries are as follows: Dakṣināmūrti and Veṇugopāla for Vaṭakke Maṭham, Pārthasārathi for Naṭuvil Maṭham, Narasiṃha for Tekkē Maṭham, Rāma for Tṛkkaikkāțưu Maṭham (Ițayil Maṭham). The branch mațhas have the same pūjā-mūrtis as their "parent" monasteries.

${ }^{20}$ All maps showing the spatial arrangement of the monastic institutions in question are 


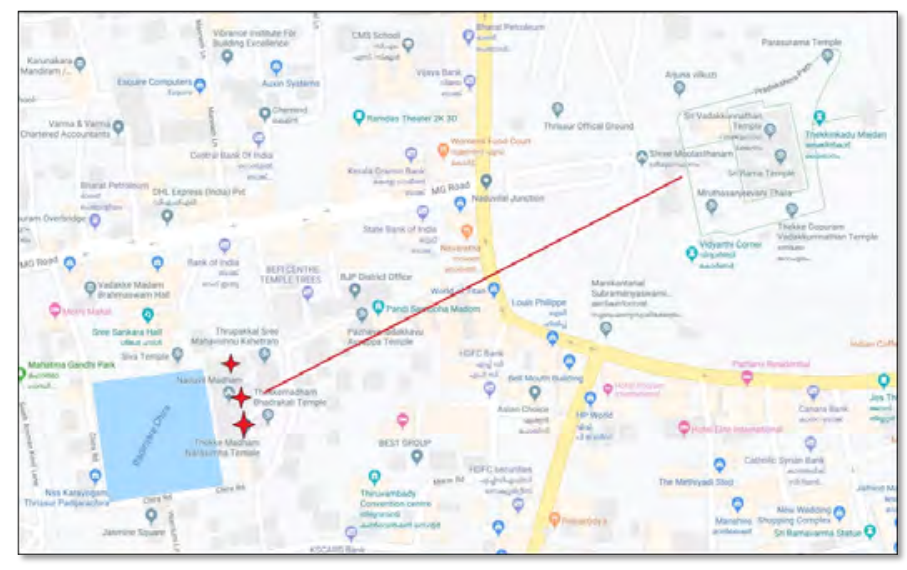

Map 3: Location of mațhas in Thrissur (map by the author based on Google Maps)

In the course of history, Nampūtiri mathas were probably deriving benefits like donations and land grants. Some donations are proved by the judgments of the Madras High Court and the Kerala State Court, which relate temple heads' litigations and claims for such proprieties as lands, temples and temples' incomes ${ }^{21}$. They were also managing (and some of them are still managing) a number of temples. Monasteries were also establishing other affiliated mațas (mal. kìlêtam mațam), most probably due to privileges and ordinances obtained from local rulers ${ }^{22,23}$. The practice of founding kîlèțam mathams seems to be a kind of tendency of network building, through an expression of "branching off", in order to establish some sort of dependance.

Thereby, the monastic institutions in question seem to have established a peculiar network of complex religious, ritualistic, economic and social inter-

prepared by the author. For this purpose I have used the Google Maps platform in combination with graphic programs. Google Maps, [www 02] (access: 27.02.2019).

${ }^{21}$ For example, Madras High Court, Naduvil Madam Parameswara vs T. P. S. Issoop Rowthan And Ors. decided on 16 September, 1924, [www 03] (access: 25.02.2019); Privy Council, Narayana Bharatigal alias Kappiyur Swamiyar Avergal; Rama Bharatigal alias Pallipat Swamiyar Avergal vs. Ittuli Amma, decided on November 02, 1916, [www 05] (access: 25.02.2019).

${ }^{22}$ C. Galewicz, Żyjące Biblioteki Indii. Rygweda braminów, p. 74.

${ }^{23}$ For instance, it is related by the local accounts that Tṛkkaikkātțu Maṭham was established in Pariyapuram village on order of Zamorin (mal. Sāmūtiri - title of the king of Kōlikkōtu) who is believed to have donated the land and financial sources for that purpose. However, it is not specified which Zamorin. Similar uncertainty applies in case of other monasteries. 
relations spreading across whole Kerala region - from North to South. The objective of the following section is to make a spatial visualisation of the network of affiliated Advaita Vedānta monasteries of Nampūtiri tradition in Kerala $^{24}$.

\section{Northern Monastery (Vațakke Mațham)}

Currently, the Vatakke Maṭam isn't a monastic institution anymore - it was transformed into vedapāthaśālā called Brahmasvam Matham ${ }^{25}$. However, a continuation of Vațakke Maṭham's ascetic tradition is believed to remain in the northern part of Kerala. The institution which is said to continue Vatakke's lineage is called Ițanir Maṭam ("mațam [which has on] its left [side] a river" ${ }^{26}$ ) - it is located in a small village Edneer (mal. Ițanīr), ca. 10 kilometres to the east of the city of Kasaragod, in the Kasaragod district. The matham is picturesquely situated on the plains, by the side of the river Madhuvahini (the name of the river comes from Sanskrit and means "honey-carrier", "honey river", "river [flowing with] a sweet nectar" - skr. madhu-vāhin $\bar{l}$ ), surrounded by the forest and paddy fields. The monastery is said to be of the Totaka parampara $\bar{a}^{27}$. The inside temple of the monastery is dedicated to two deities: Dakṣiṇāmūrti and Gopālakṛ̣ṇna ${ }^{28}$ - noteworthily, the only person allowed to perform $p \bar{u} j \bar{a}$ (the ritual of worshiping the deities) in this temple is the head ${ }^{29}$ of the monastery (mal. svāmiyār) ${ }^{30}$. The hill

${ }^{24}$ I enumerate in this section monasteries which have remained. Presented data concerning four primary mathas in Thrissur and its branches were gathered during my recent fieldwork in Kerala in 2018.

${ }^{25}$ Dating of Vațakke Matham itself and its transformation into vedapạthaśālā remains uncertain. However, Brahmasvam Matham is discussed on the basis of historical record in the book by Ananda E. Wood Knowledge before printing and after. The Indian tradition in changing Kerala - therefore it is certain that it has already existed in the late 19th century. A. E. Wood, Knowledge Before Printing and After. The Indian Tradition in Changing Kerala, pp. 26-43.

${ }^{26}$ The name of the village and of the matha comes from Kannada: eda - "left side", niru "water".

${ }^{27}$ As its "parent monastery" - Vaṭakke Maṭham in Thrissur.

${ }^{28}$ The inside temple of the "parent monastery" - Vatakke Mațham in Thrissur - is dedicated to the same pair of deities.

${ }^{29}$ Keśavānanda Bhāratī is the current head of Ițanīr Matham (at the time of my visit in 2018).

${ }^{30}$ It is peculiar custom because, according to the Hindu orthopraxis, after being initiated into samnnyāsa (renunciation) person withdraws oneself from all ritualistic activities. G. Flood, Hinduizm, pp. 95-96. 
located on the northern side of the monastery ${ }^{31}$ seats the Viṣumangala Temple. Two main mürtis (idols) of the temple are of Mahāviṣnu (idol faces east) and Dakșināmūrti (idol faces south). On the temple premises (on the western side of the temple) there is a samādhi of a local ascetic known as Nīramuni. The Viṣnumangala Temple is managed by Ițanīr Maṭham ${ }^{32}$.

According to the local accounts (which are in circulation in Edneer, as well as in Thrissur), in the past, a Sivalli brahmin ${ }^{33}$ was believed to be the head of Vatakke Matham in Thrissur. For some reason, he didn't initiate any samnyāsin, as his successor ${ }^{34}$ left the monastery, which then became a vedapāthaśâla nowadays known as Brahmasvam Matham, and set out for the $y \bar{a} t r \bar{a}$ (pilgrimage) directing to the north - as the popular legend relates ${ }^{35}$. During his pilgrimage, he was believed to reach Edneer in the north of Kerala, and to establish a new matham (branch of Vatakke Matham) there, due to the request of the local Yādava community. The local account relates that afterwards, Śivallị Svāmiyār was granted land and necessary resources by the Yādava community and Rājā of Kumbal $a^{36}$ to build a monastery in Edneer ${ }^{37}$. This is how the local oral tradition explains the origin of the Itanīr Matham in the Kasaragod district - unfortunately no reliable historic documents concerning the establishment of this institution are known to me at the current stage of my research.

Itanīr Mațam is said to have a branch mațam (mal. kịlêțam mațam) in Taliparamba (mal. Talipparampu ), in the Kannur district, ca. 80 kilometres south of Edneer. It is situated in close proximity to the famous Truccambaram Śrikrṣna Temple. It is believed that several samādhis of previous Ițanīr Matham Svämiyārs are located on the premises of the branch mațha ${ }^{38}$.

${ }^{31}$ The temple is situated just 200 meters away from the matham.

${ }^{32}$ Information provided by Keśavānanda Bhāratī - Ițanīr Maṭham Svāmiyār in 2016.

${ }^{33}$ Hindu community which comes from Tulu Nadu.

34 There are two versions of the legend which are known to me. One states that the Svāmiyār left the matham because of the conflict with the other heads of the Thrissur monasteries who were Nampūtiris and thus didn't accept the Sivalli Svāmiyār. Second relates that he didn't give samnyāsa to anyone because he did not want to cause any suffering to a mother of a potential ascetic. [Local accounts gathered by the author during fieldwork in Kerala in 2018].

35 The narrative apparently forms also an important part of the Brahmasvam Matham's foundation myth.

${ }^{36}$ No information which specifies which particular king.

${ }^{37}$ Ițanīr Mațam leaflet.

${ }^{38}$ There are twelve samādhis on the premises of Iṭanīr Maṭham in Edneer (only two - the most recent - are dated). 
Iṭanīr Maṭham Svāmiyār sojourns in this monastery once a year during the annual Tṛccambaram Srìkṛ̣na Temple festival held in March $^{39}$. Thus, the mathas seem today to live a fragmentary life tied to the periodical presence of the Svāmiyār.

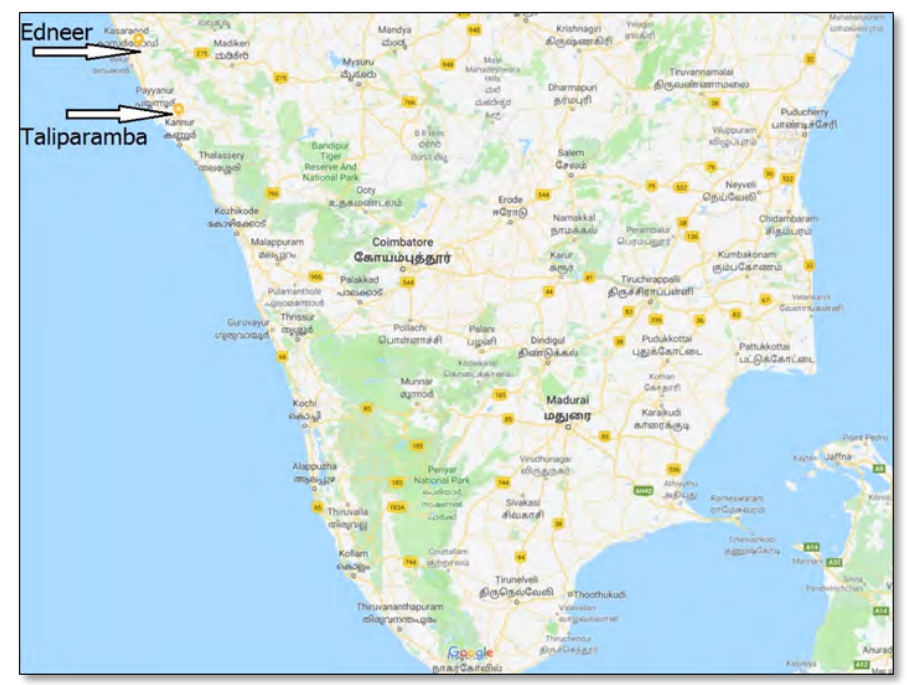

Map 4: Location of Ițanīr Mațhas (map by the author based on Google Maps)

The peculiar feature of the Itanīr Matham is certainly the fact that the Svāmiyārs of this monastery are Sivalli brahmins and not Nampūtiris - as claimed by Ițanīr Maṭham Svāmiyār Keśavānanda Bhāratī. However, despite that, it is considered to be a continuation of the Vatakke Matham ascetic lineage either by Nampūtiri Svāmiyārs from other monasteries (i.e. Națuvil, Tṛkkaikkātțu, Muñcira and Tekkē Mațham) and Ițanīr Maṭham Svāmiyārs themselves. This direct affiliation was very recently to be observed during the official ceremony of the unveiling the newly built statue of Sankara in front of Tekkē Mațham in Thrissur. Iṭanīr Mațham Svāmiyār was invited there to officiate in the consecration ceremony, while Svāmiyārs from Tekkē and Muñcira Maṭham were delivering blessing speeches ${ }^{40}$.

${ }^{39}$ Information provided in the interview by Ițanīr Maṭham Svāmiyār Keśavānanda Bhāratī in 2016.

${ }^{40}$ Information obtained form Tekkē Matham manager during fieldwork in 2018. 


\section{Middle Monastery (mal. Națuvil Maṭham)}

Națuvil Matham is one of the four monasteries established - allegedly by Sankara - in Thrissur. It has survived until today, and it remains an active monastic institution. Dating of Națuvil Mațham remains still uncertain. In the inside temple of the monastery - Pārthasārathi Temple - in Thrissur, there is an inscription which was estimated by Prof. Kesavan Veluthat to come from ca. the 18th-19th century (in personal communication: 10.12.2018, Kodungallur). The inscription is in modern Malayalam script, in two languages: Sanskrit and Malayalam. According to Prof. Veluthat, it is possible that the inscription concerns the rebuilding of the matham - putting down the old structure and building a new one ${ }^{4}$. However, we can certainly trace Thrissur Natuvil Matham's history back in time until the year 1846, due to the recorded judgment of the Privy Council in the case Naduvil Madan Parameswar Bharatigal vs. Tpsissoop Rowther decided on September 16, 1924. It is clearly stated in the judgement that according to the presented exhibits, one Viṣnu Bhāratī was the Thrissur Naṭuvil Maṭam Svāmiyār in the year $1846^{42}$.

Naṭuil Maṭham is believed to belong to the Sureśvara parampara $\bar{a}^{43}$. The monastery is said to possesses one branch matham in the city of Thiruvananthapuram (mal. Tiruvanantapuram) - the capital of Kerala state. Thiruvananthapuram is ca. 280 kilometres south of Thrissur. The branch mațam is located in Mithranandapuram (mal. Mitrānandapuram) ${ }^{44}$, West Fort, ca. 0,5 kilometres to the west from the prominent Padmanābhasvāmī Temple - therefore it is also called Pațiñnāru Maṭam ("Western Monastery"). The monastery stands by the Mithranandapuram Pond, next to the Vilvamanggalam Śrîkṛṣna Temple. Mithranandapuram copper-plate inscriptions prove that the samnya āsi-mața in Mithranandapuram was already in existence in ca. 12th century ${ }^{45}$. However, it doesn't confirm that it was the Advaita Vedānta institution at that time. Probably the affiliation with Sankara is posterior ${ }^{46}$.

${ }^{41}$ The information about the inscription I owe to dr Hugo David.

$4^{2}$ Privy Council, Naduvil Madan Parameswar Bharatigal vs. Tpsissoop Rowther decided on September 16, 1924, [www 07] (access: 18.02.2019).

${ }^{43}$ It is headed by Maravancērry Tekkēṭattu Nīlakaṇthan Bhāratīkal Svāmiyār (at the time of my visit in 2018).

${ }^{44}$ Mithranandapuram forms a part of Thiruvananthapuram.

${ }^{45}$ K. V. Subrahmanya Aiyar, Travancore Archeological Series. Stone and Copper-Plate Inscriptions of Travancore with 26 Plates, Vol. III, Part I, pp. 1-25.

${ }^{4} 6$ According to Prof. Kesavan Veluthat (in personal communication). 


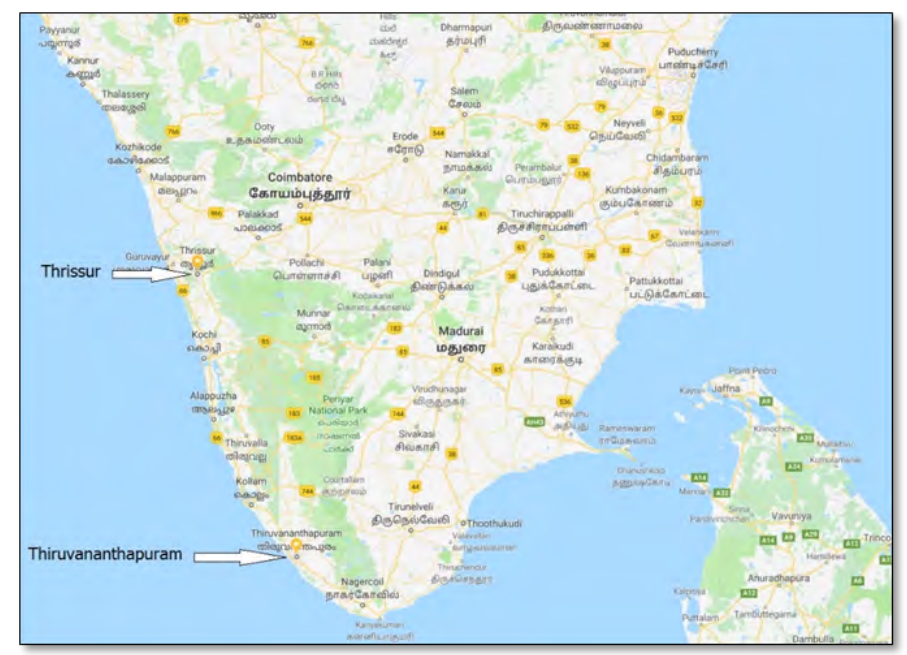

Map 5: Location of Natuvil Mațhas (map by the author based on Google Maps)

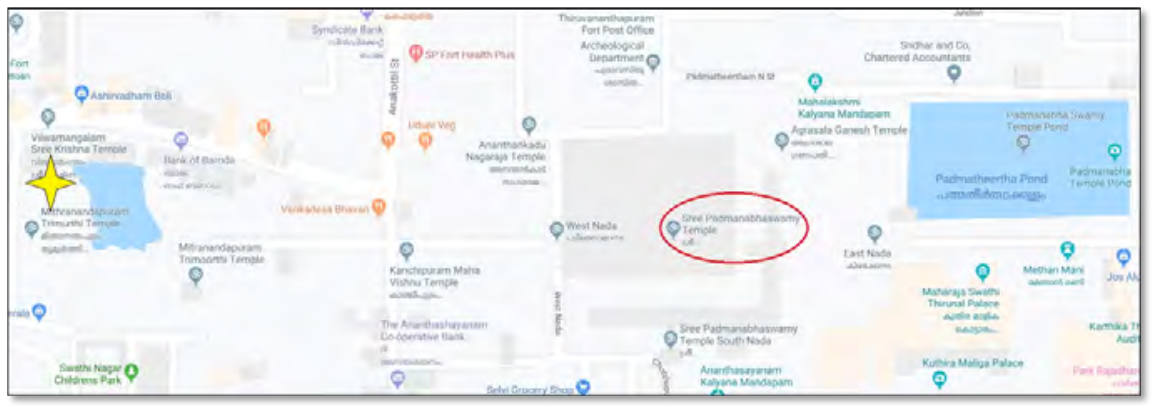

Map 6: Location of Națuvil Mațam in Mithranandapuram (map by the author based on Google Maps). Yellow star marks the location of Natuvil Matham branch in Mithranandapuram. 
The Śrìnṣna Temple is believed to have been built on the samādhi of the legendary saint Vilvamangalam, who is the protagonist of the founding myth of the Padmanābhasvāmī Temple ${ }^{47}$. The temple belongs to Natuvil Matham ${ }^{48}$. Inside the temple, in front of the idol of the main deity, stands a small metal statuette, picturing the ascetic, Vilvamangalam. According to the local accounts, Vilvamangalam is believed to be the first Svāmiyār of the Natuvil Matham who succeeded Śankkara's disciple - Sureśvara. He is also said to be the first Puṣpāñjali49 Svāmiyār in the Padmanābhasvāmī Temple. Thus, the personage of Vilvamangalam Svāmiyār links two legends: about the origin of the one of the most important south Indian temples - Padmanābhasvāmì Temple - and the beginnings of Natuvil Matham ${ }^{50}$.

Apart from the samādhi of Vilvamangalam, there are two other samādhis located next to the Mithranandapuram matham. One is anonymous and

47 The legend states that: at the time of Vilvamangalam Svāmiyār's meditational life in the Anantapuram Temple at Kasaragod, the god Viṣnu appeared to him in a boy's form. One day, the boy took Svāmiyār's śālagrāma (a sacred stone worshipped by the Vaiṣnavas) and bit it. Seeing this, Svāmiyār became angry and pushed him. The boy then said in sorrow: "If you want to see me again, you should come to Anantavanam ('forest named Ananta')." Saying this, he disappeared. Due to the affection to the boy, a suffering Svāmiyār reached Anantavanam. There, he saw the boy running to a big ilippa tree (Madhuca longifolia) and merging with it. The tree fell down and transformed into Anantapadmanābha's form (manifestation of god Viṣnu, from whose navel sprang the lotus which contained the god Brahmā, reclining on the serpent Ananta). Only then, did Svāmiyār realise that the boy is the god Viṣnu himself. The lord's head was in Thiruvalla (mal. Tiruvalla), body in Thiruvananthapuram, and feet in Thrippappur. Vilvamangalam then prayed that the god shorten his body to measure three times the length of his danda ("stick of an ascetic"), so that he can circumambulate and pay obedience to the deity. Viṣnu fulfilled Vilvamangalam's prayer. Thereafter, the ascetic circumambulated the deity and made an offering of tender mangos and flowers. For daily worship, the great temple was constructed in the present day Thiruvananthapuram. From that time onwards, pușpāñjali was conducted daily, and because of that, Svāmiyār stayed premanently in a parnaśāalā ("leaf-hut") on the western side of the temple. [Source: private notes of the Națuvil Maṭham Svāmiyār - Maravancērry Tekkētattu Nīlakaṇthan Bhāratīkal].

${ }^{8}$ Information provided by the priest officiating in the Vilvamangalam Śrìkṛṣna Temple during the interview in 2016.

${ }^{49}$ Ritual offering of the flowers for the temple deity. The title Puṣpāñjali Svāmiyār suggests privilege as well as obligation.

$5^{\circ}$ The cited legends are available in the extensive collection of the Keralan legends compiled in the book Aitihyamāla (Garland of legends) by Kottarathil Sankunni (1855-1937). They were first published in the early zoth century in the magazine "Bhāṣāpōṣiṇi”. In 2016, an English translation was published in two volumes: K. Sankunni, Aithihyamaala. The Great Legends of Kerala, Vol. 1, Vol. 2, S. Ramachandran (trans.), 2016. 
undated, the other one is of Sarasvatī Tīrtha Svāmiyār from the year 1143 Kollam Era (1968 year in Gregorian calendar).

By tradition, Natuvil Matham Svāmiyārs are entitled to perform daily puṣpāñajali rituals in the Padmanābhasvāmī Temple - which is an exclusive privilege, duty and honour interlinking the two institutions in a service exchange that recurs regularly on a yearly basis. They preside also over the Ețtarayōgam - the body of Padmanābhasvāmī Temple trustees. Thus, due to his ritual obligations, Națuvil Mațham Svāmiyār resides permanently in the branch mațam in Thiruvananthapuram ${ }^{51}$. He visits occasionally Natuvil Matham in Thrissur. Nowadays, because no samnnyāsin is staying there, Brahmasvam Matham students practice Vedic recitation in the space of Natuvil Maṭham.

\section{In-between Monastery (mal. Ițayil Mațham)}

The Ițayil Matham (In-between Monastery), according to the Keralan hagiographic tradition of Sankara, was believed to be one of the four mathas established by the philosopher in Thrissur. However, today, no such monastic institution remains in this city. Local accounts relate that it was relocated outside the town. It is the monastery which is known currently under the name Tṛkkaikkātțu Maṭham, which is considered to be the shifted Iṭayil Mațham. Tṛkkaikkāttu Matham ${ }^{52}$ is located in the Pariyapuram (mal. Pariyāpuram) village, near to the city of Tanur (mal. Tānūr) in the Malappuram (mal. Malappuram) district. The place is situated ca. 8o kilometres north-west of Thrissur. The monastery is located next the small hill, which seats the Śrī Tṛkkaikkāțtu Siva Temple - the temple belongs to Tṛkkaikkātțu Maṭam. The land for establishing the matha is believed to be granted by one of the Zamorins, as claimed by the mațas trustees - although this information, for the time being, is unconfirmed.

${ }^{51}$ G.L. Bayi, Sree Padmanabha Swamy Temple, pp. 310-314.

$5^{2}$ The name of the matha refers to the founding myth of the monastery. According to legend, one Namputiri brahmin had a visualisation of the Siva's auspicious hand in the forest. The Siva temple was built in the location where the god's hand was seen by a devotee, and the place took the name Tṛkkaikkātțu - "forest of the auspicious hand". This land is believed to be given to Ițayil Maṭham by Zamorin, for constructing the mațam there, which was named after the Tṛkkaikkātțǔ Temple (source: mațha’s leaflet). 
The dating of this institution is uncertain. However, it is possible to trace its history back in time until the year 1854 , due to the recorded judgment of Madras High Court in the case: Trikkaikkat Madathil Raman vs. Thiruthiyil Paramal Krishnan decided on 10 November, $1905^{53}$.

On the mațha premises, there are five samädhis of previous Svāmiyārs. The monastery is said to be of Totaka parampara $\bar{a}^{54,55}$. The mața is an active centre, open to all people - Svāmiyār is giving regularly lectures on Vedānta - and functions also as the yogāśramam where Svāmiyār gives daily yoga and meditation classes for male and female students. Moreover, on each Sunday, Svāmiyār usually accepts (numerous as I witnessed) visitors, who come to him in order to discuss their personal problems and ask for his advice.

Tṛkkaikkātțu Mațham is said to have a branch mațha located in the city of Kottayam (mal. Kōtțayam) (i.e. ca. 210 kilometres south of Pariyapuram) ${ }^{56}$. The monastery is located in Tirunakkara (mal. Tirunakkara) ${ }^{57}$, ca. 200 metres from the important śaiva temple, situated on the hill - the Tirunakkara Mahādeva Temple. The founding myth of the Tirunakkara Mahādeva Temple makes a link between the temple and Tṛkkaikkāțtu ${ }^{\sim}$ Maṭam in Tirunakkara ${ }^{58}$. There are two samādhis of previous Svämiyārs on the premises of the matham. Inside the monastery, there is the Rāma-Hanumat Temple, next to the mața there is Śrī Śnikara Mandapam (hall) where various cultural programs take place. It is said that few years back, the monastery was in ruin, but ca. six years ago, a local Trust was established to run the matha - it renovated the building of the monastery together with its surroundings, and constructed

${ }^{53}$ Madras High Court, Trikkaikkat Madathil Raman vs. Thiruthiyil Paramal Krishnan decided on 10 November, 1905, [www 04] (access: 12.02.2019).

54 This is a controversial issue because according to the vernacular legend, Hastāmalaka was said to be the first head of Iṭayil Maṭham. Thus, Tṛkkaikkāțǔ Maṭham supposed to be a Hastāmalaka paramparā.

${ }^{55}$ Kụṣna Brahmānanda Tīrtha Svāmiyār is the current Svāmiyār of Tṛkkaikkātṭu Maṭham in Pariyapuram (at the time of my visit in 2018).

${ }^{56}$ It is headed by Vāsudeva Brahmānanda Tīrtha Svāmiyār (at the time of my visit in 2018).

${ }^{57}$ Area name of Kottayam. Tirunakkara means "the holy Nakkara [hill]".

${ }^{58}$ The local legend relates that on the grounds of the present Tirunakkara Mahādeva Temple, there was earlier a place to grow vegetables for the branch Tṛkkaikkāțu \aṭham. Once upon a time, while people were farming the vegetables there, they heard some noise and suddenly saw a Siva-linga. They got afraid and ran to Svämiyār. The ascetic came there and recognised svayambhü Siva-linga. Svāmiyār then informed the Tekkumkūr Rājā about the miraculous event. The king built the Tirunakkara Mahādeva Temple and the svayambh $\bar{u}$ Siva-linga was installed there (source: mațh's leaflet). 
an adjoining maṇdapam. Tṛkkaikkāț̣u Maṭham in Kottayam appears to be an active cultural center - regular Sanskrit courses are taking place there, Advaita Vedānta lectures are held there each week (given by local scholars, not Svāmiyār himself), kathakali performances are staged there as well etc ${ }^{59}$.

Despite that, Tṛkkaikkāțư institutions seem to be less known than the Natuvil and Tekkē Matham, they appear nowadays to be well prospering monasteries. In fact, Tṛkkaikkāttu mathas seem to be more active than the ossified Natuvil Maṭham and Tekkē Matham, and the lineage more secure it is the only monastic institution, of the ascetic tradition in question, which has simultaneously two Svāmiyārs (one residing in Pariyapuram, and the second in Kottayam $)^{60}$. Moreover, Tṛkkaikkātțu Mațham has its sublineage - which I'm going to discuss in the following section - Muñcira Mațam.

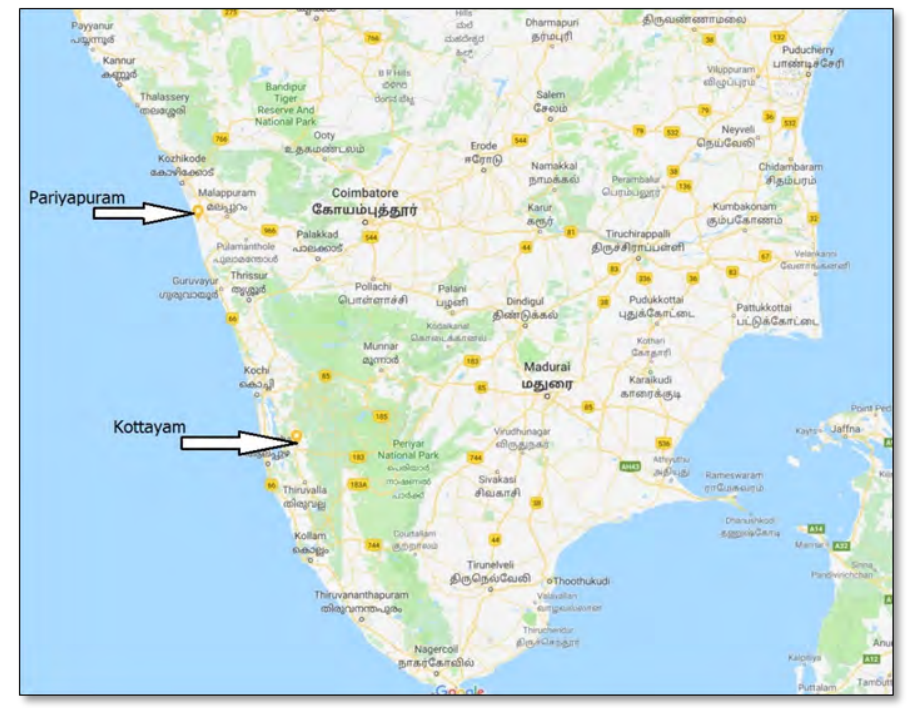

Map 7: Location of Tṛkkaikkāțtu` Mațhas (map by the author based on Google Maps)

59 Information provided by the matha's trustees during fieldwork in 2016.

${ }^{60}$ Moreover, on the date 16-18.03.2019 there is planned an initiation ceremony (skr. $\left.d \bar{\imath} k s \underline{a}\right)$ of a new samnnyāsin in Tṛkkaikkāțtu Mațham in Pariyapuram (as I was informed by the manager of the matha during fieldwork in 2018). 


\section{Branch Monastery - Muñcira Mațham}

Tṛkkaikkāțu〕 Maṭham is said to have another branch mațha - Muñcira Matham - which constitutes a kind of sub-lineage. The ascetic tradition of Muñcira Matham was recently extinguished for a period of time: since 2004 until 2011; and since 2014 until 2017. The current head of the math ${ }^{61}$, according to the Muñcira Matham's paramparāa, is the 48th Svāmiyār of the monastery $^{62}$. He was initiated by the Tṛkkaikkātțu Maṭam Svāmiyār from Pariyapuram. The main Muñcira Mațham is located in the small village of Munchirai (mal. Muñcirai), situated ca. 10 kilometres from the city of Marthandam (mal. Mārttāṇụam) in the Kanyakumari district of Tamil Nadu (in former Travancore State, mal. Tiruvitānkūr) - this is ca. 50 kilometres south from Thiruvananthapuram. Unfortunately the monastery is nowadays abandoned and the building itself is in ruin. There are two copper plate inscriptions belonging to Muñcira Matham, suggesting the age of this institution. One is dated to ca. the beginning of the 13th century and consists of details of an income set apart for feeding persons on $d v \bar{a} d a s$ is days of the 12 months of the year, and of registered gifts made for feeding on other occasions of some of the persons. It is written in Vatteluttu script ${ }^{63}$. The second one records an agreement between Kunnūr Nambūri (Nampūtiri?) and the Svāmiyār about the management of the samudāyam of the temple at Avittathur (mal. Avițtattūr). It is dated to ca. 1770. It is written in Vațteluttu script, in the Malayalam language ${ }^{64}$.

The mațha is situated next to the Bhagavatī/Rāma Temple ${ }^{65}$. There are eight samädhis on the temple premises (of which one is dated to 1974). The monastery is said to have its branch in Thiruvananthapuram - Muñcira Kilakku ${ }^{66}$ Matham - which is located in the East Fort, on the east side of the Padmanābhasvāmī Temple. Muñcira Maṭham Svāmiyār resides permanently in the branch matham in Thiruvananthapuram, due to the ritual con-

${ }^{61}$ Parameśvara Brahmānanda Tīrtha (at the time of my visit in 2018).

${ }^{62}$ Muñcira Matham Website, [www 06] (access: 15.02.2019).

${ }^{63}$ K. V. Subrahmanya Aiyar, Travancore Archeological Series. Stone and Copper-Plate Inscriptions of Travancore with 26 Plates. Vol. III, Part I, pp. 207-211.

${ }^{64}$ T. A. Gopinatha Rao, Travancore Archeological Series, No. VII, pp. 301-302.

${ }^{65}$ There are two main mūrtis in the temple: of Rāma and Bhagavatī. Originally it was Rāma Temple.

${ }^{66}$ Mal. kilakku means "east". The name of the Muñcira branch mața is often shortened to Kilakku Matham - "Eastern Monastery". 
nection with Padmanābhasvāmī Temple. Muñcira Maṭham Svāmiyārs - together with Națuvil Maṭham Svāmiyārs - have a right and privilege within the liturgical life of the Padmanābhasvāmī Temple, they are appointed as Puṣpāñjali Svāmiyārs in the temple. Each of the Svāmiyārs fulfills his ritual duties in the Padmanābhasvāmī Temple for a half of a year, after that time they switch ${ }^{67}$.

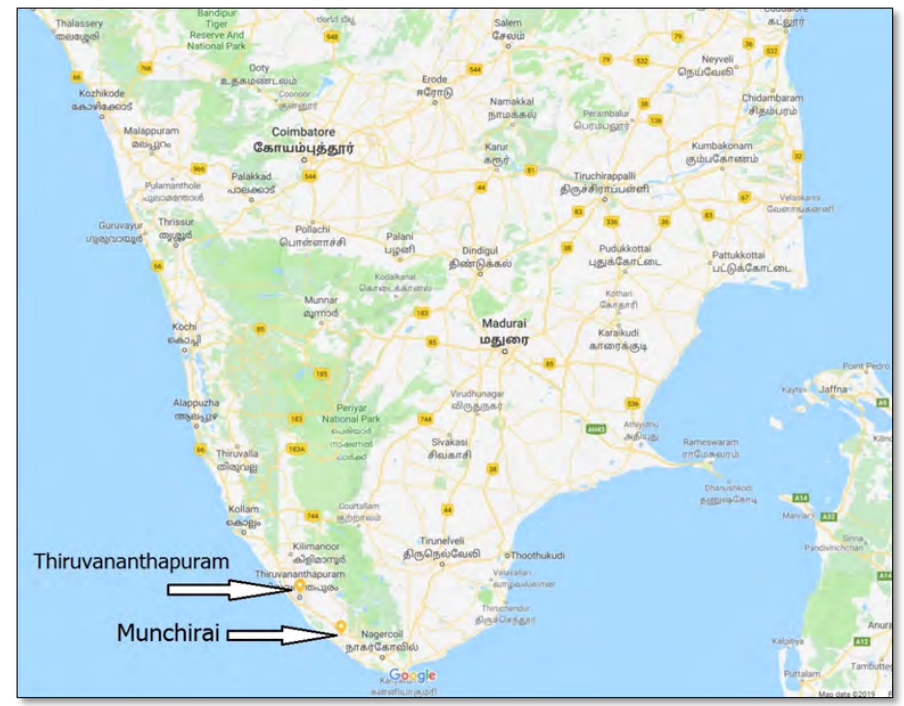

Map 8: Location of Muñcira Mațas (map by the author based on Google Maps)

Noteworthily, just like the Vațakke Mațham ("Northern Monastery") and Tekkē Matham ("Southern Monastery") have the cardinal directions in their names, the branch mațhas of Națuvil Mațham and Muñcira Maṭam in Thiruvananthapuram also bear the cardinal directions in their names: Kilakku Matham ("Eastern Monastery" - branch of Muñcira Matham) and Pațiñnāanu Maṭham ("Western Monastery" - branch of Națuvil Mațam) - however, these institutions have as a reference point the Padmanābhasvāmī Temple (they are located close to the temple because its Svämiyārs perform pușpāñjali there).

${ }^{67}$ Information provided by Tekkē Matham manager during fieldwork in 2018. 


\section{Southern Monastery (mal. Tekkē Maṭham)}

Tekkē Matham is one of the four monasteries established allegedly by Sankara in Thrissur. It has survived until today, and remains an active monastic institution. The dating of Tekkē Matham remains uncertain. However, we can trace the history of Tekke Matham in Thrissur back in time until the year 1041 Kollam Era (1866 year of Gregorian calendar). It is possible on the basis of the colophon in the palm-leaf manuscript no. 125, which is kept in Vatakke Matham Brahmasvam Vedic Research Centre in Thrissur (the manuscript belonged earlier to Tekkē Matham). The manuscript contains the text Yatidharmmasamuccaya, which ends with the colophon giving inter alia such information as: the year of writing down the text (1041 Kollam Era), the name of the person who ordered writing down the text - i.e. Putumana Ceriya Tirumanassa, who is described to be Tekkē Matha Svāmiyār ${ }^{68}$.

Tekkē Maṭham is said to belong to the Padmapāda parampara $\bar{a}^{69}$. The current Tekkē Matham Svāmiyā $r^{70}$, according to the monastery's paramparā is the 84th Svāmiyarr of the monastery. On the premises of the matha, there is one samādhi-mandapa of the previous Tekke Svāmiyār ${ }^{71}$. Recently, the institution seems to be quite active due to the vision of its manager - Vadakkumpad Narayanan - who initiates new undertakings in the matha such as: the building of the statue of Sankara in front of the monastery, constructing the Sribhadra Mandapam (venue hall) also in front of the monastery, organising the ācāryasamgamam (meeting of Advaita Vedānta ascetics) in Tekkē Maṭham (28.12.2018) etc. The monastery is said to possess one branch matham in the village Thiruvarpu (mal. Tiruvārppu`), in Kottayam district. Thiruvarpu is located ca. 130 kilometers south of Thrissur. Svāmiyār is said to visit branch matha in Thiruvarpu once a month and stay there for 10 days to perform puṣpāñali in the Śrī Kṛ̣ṇa Temple, which is situated close to the monastery. It is believed that there are several samādhis on the premises of the Thiruvarpu monastery ${ }^{72}$.

\footnotetext{
${ }^{68}$ Manuscript consulted by the author.

${ }^{69}$ It is headed by Vāsudevānanda Brahmānanda Bhūti Svāmiyār (at the time of my visit in 2018).

${ }^{70}$ At the time of my visit in 2018.

${ }^{71}$ Śankkarānanda Brahmānanda Bhūti.

${ }^{72}$ Information provided by Tekkē Matham manager during fieldwork in 2018.
} 


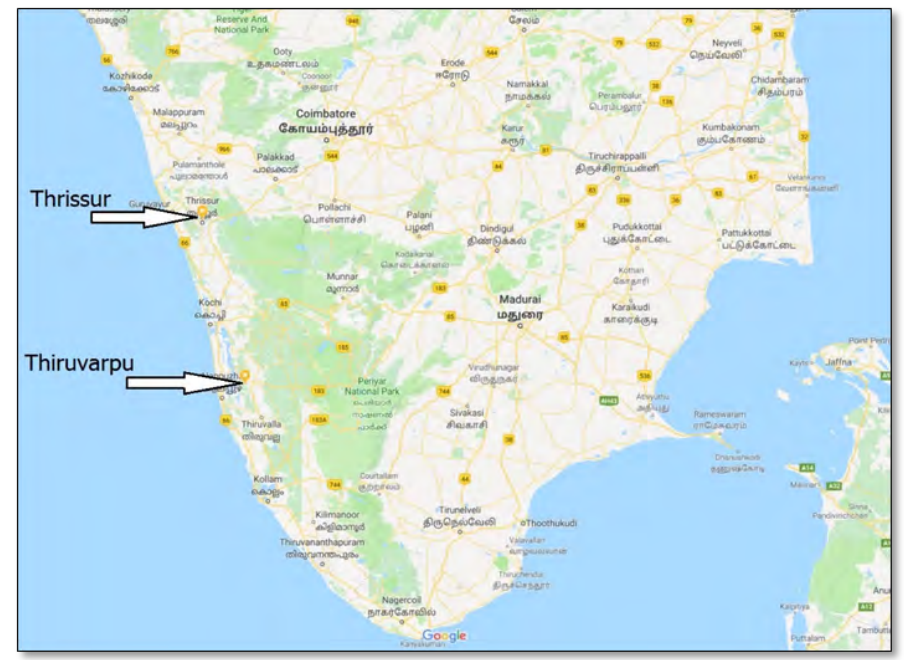

Map 9: Location of Tekkē Mathas (map by the author based on Google Maps)

\section{Conclusion}

Though this paper is merely a short introduction to the subject of the Advaita Vedānta monasticisms of Nampūtiri tradition in Kerala, its primary objective was especially to present and focus on the spatial distribution of the discussed institutions. Due to the presented cartographic visualisation, it became apparent that the monastic tradition in question have, in the past, created a network of intricate ritualistic, economic, social and political interrelations spreading across whole Kerala region. How these institutions have been functioning in a symbolic, cultural and geographic space, still remains uncertain and needs further examination. However, the spatial analysis of the Nampūtiri mathas can yield some vital clues about the influence and significance of those institutions in the society, as well as about their associations with particular local kingdoms and its rulers etc. in a situation where reliable historical records are very scant. The use of a map as an analytical tool appears to be very revealing while working with such material. Thus, the map helps to determine orientation, spatial arrangement, territorial demarcations, hierarchy, reference points, juxtaposition of spaces, interrelationship of monasteries, subordinate temples and wider landscape. As a result, we realise the spatial qualities of the mathas' geographical distribution - the central position of clustered "parent" monasteries in Thrissur which radiate 
on whole region of Kerala. Visual evaluation of the Nampūtiri mațas' spatial arrangement in the context (contextual spatiality ${ }^{73}$ ) of the pan-Indian Advaita monasticism, allows also to recognise ideological content in its spatial expression - the digvijaya concept. Therefore, in the final conclusion, instead of words, I'm going to use the map itself (placed below) which presents a whole picture of the elaborate network of Nampūtiri monastic institutions of Advaita Vedānta tradition in Kerala.

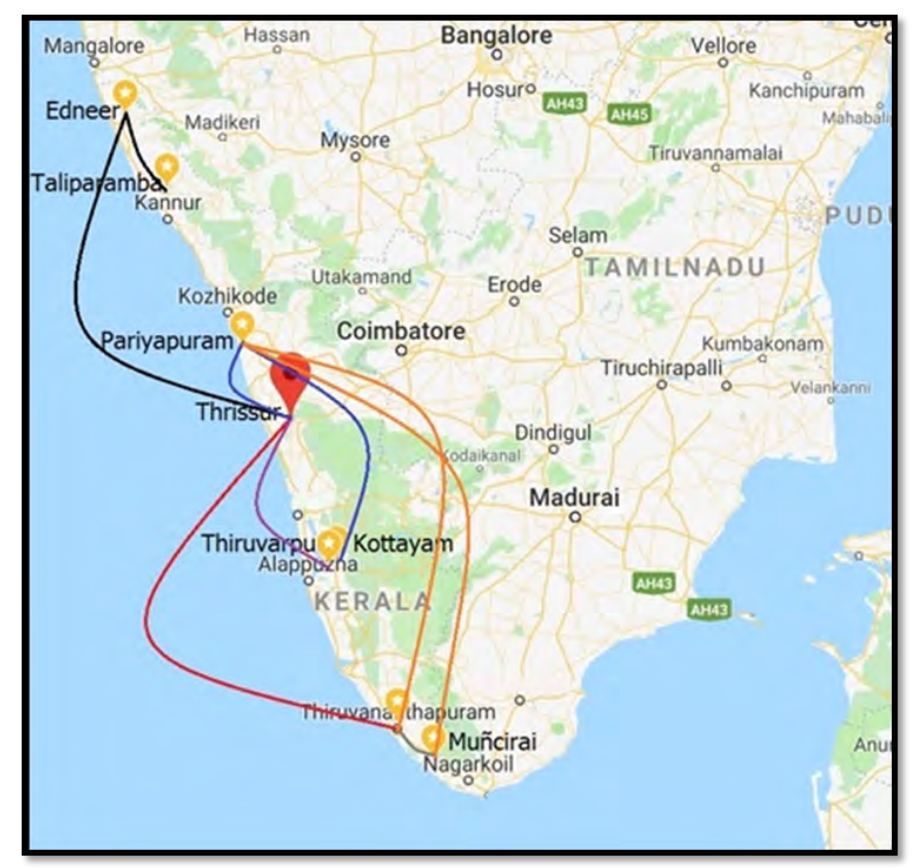

Map 10: Network of Advaita Vedānta Mathas of Nampūtiri tradition in Kerala (map by the author based on Google Maps).

\section{Legend:}

City of Thrissur is marked with a red pin.

Yellow stars mark cities where branch mathas are located.

Black line marks the network of Vațakke Matham (Itanīr Mațam) institutions

Blue line marks the network of Tṛkkaikkātțu Matham (Ițayil Matham) institutions

Orange line marks the network of Tṛkkaikkāțtǔ Maṭam affiliation

Red line marks the network of Natuvil Matham institutions

Violet line marks the network of Tekkē Matham institutions

Grey line marks the network of Muñcira Matham institutions

${ }^{73}$ Term used by Miki Desai in: M. Desai, Wooden Architecture of Kerala, p. 165. 


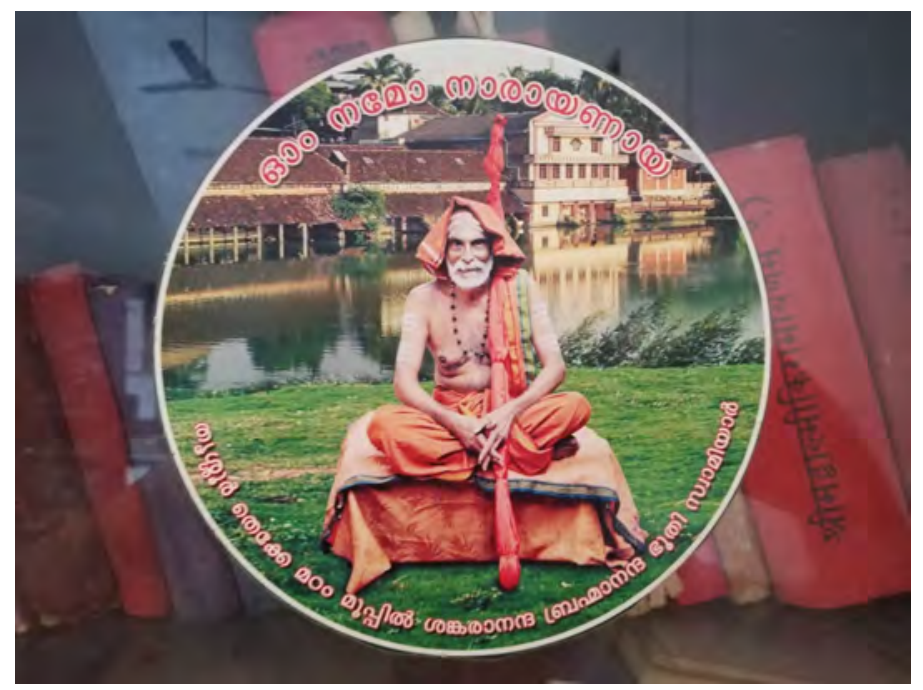

Photo 1: Previous Tekkē Maṭham Svāmiyār with the Thrissur mațas in the background. A piece of the monastery's self-representation policy - matha's promotional material (a sticker).

\section{Bibliography}

1. Achyuthan A., Balagopal T. S. Prabhu, An Architectural Guide of Thrissur, Vāstuvidyāpratișthānam, Calicut 1996.

2. Antarkar W. R. (ed.), Śä́karācāryacarita (Govindanātha), "Bharatiya Vidya" 52 (1-4)/ 1992, pp. 57-140.

3. Antarkar W. R., Śankara-Vijayas. A Comparative and a Critical Study, Veda Sastra Pandita Raksha Sabha, Mumbai 2003.

4. Antarkar W. R., Śankkara-Vijayas. A Comparative and a Critical Study. Appendix, Veda Sastra Pandita Raksha Sabha, Mumbai 2003.

5. BADER J., Conquest of the Four Quarters: Traditional Accounts of the Life of Śankara, Aditya Prakashan, New Delhi 2000.

6. BAy G. L., Sree Padmanabha Swamy Temple, Bharatiya Vidya Bhavan, Mumbai 2013.

7. Berti D., Good A. \& Tarabout G. (eds.), Of Doubt and Proof. Ritual and Legal Practices of Judgment, Routledge, London 2015.

8. Clark M., The Daśanāmì-Samnnyāsīs. The Integration of Ascetic Lineages into an Order, Brill's Indological Library, Leiden 2006. 
9. Desai M., Wooden Architecture of Kerala, Mapin Publishing, Ahmedabad 2018.

10. Flood G., Hinduizm, Wydawnictwo Uniwersytetu Jagiellońskiego, Kraków 2008.

11. Galewicz C., Żyjące biblioteki Indii: Rygweda braminów Nambudiri, Wydawnictwo Uniwersytetu Jagiellońskiego, Kraków 2015.

12. IrIngalakuda R., Śrī Śañkara Darśanavum Svāmiyār Maṭañnalum, Sirigannada Offset Printers, Kasaragod 2000.

13. Iringalakuda R., Mutts and Missions in Kerala, Thriveni Books, Thrissur 2016.

14. Kulke H., Rothermund D., A History of India, Routledge, London 2004 .

15. Menon A. S., Kerala District Gazetteers: Trichur, Bhagyodayam Press, Thiruvalla 1962.

16. Menon A. S., A Survey of Kerala history, National Book Stall, Kottayam 1970.

17. Menon A. S., Cultural Heritage of Kerala. An Introduction, East-West Publications Private LTD, Cochin 1978.

18. Menon A. S., Social and Cultural History of Kerala, Sterling Publishers PVT LTD, New Delhi 1979.

19. Parpola M., Kerala Brahmins in Transition. A Study of a Nampūtiri Family, Gummerus Printing, Helsinki 2000.

20. Rao T. A. Gopinatha, Travancore Archeological Series, No. VII, Methodist Publishing House, Madras 1911.

21. Sankunni K., Aithihyamaala. The Great Legends of Kerala, Vol. 1, Vol. 2, Ramachandran S. (trans.), Mathrubhumi Books, Kozhikode 2016.

22. Sax W. S., Conquering the Quarters: Religion and Politics in Hinduism, "International Journal of Hindu Studies" 4/1 (2000), pp. 39-6o.

23. Subrahmanya K. V. Aiyar, Travancore Archeological Series. Stone and Copper-Plate Inscriptions of Travancore with 26 Plates, Vol. III, Part I, Government Press, Trivandrum 1921.

24. Sundaresan V., Conflicting Hagiographies and History: The Place of Śankaravijaya Texts in Advaita Tradition, "International Journal of Hindu Studies" 4/2 (2000), pp. 109-184.

25. Swami Anantanandendra Saraswati, Śri Śankkara and Śankarite Insitutions, [in:] Preceptors of Advaita, Mahadevan T. M. P. (ed.), Sri Kanchi Kamakoti Sankara Mandir, Secunderabad 1968, pp. 376-401. 
26. Veluthat K., Brahman Settlements in Kerala. Historical Studies, Cosmo Books, Thrissur 2013.

27. Wood A. E., Knowledge before printing and after. The Indian tradition in changing Kerala, Oxford University Press, Delhi/Bombay/Calcutta/ Madras 1985 .

\section{Internet sources:}

[www 01] https://earth.google.com (access: 27.02.2019)

[www 02] https://www.google.com/maps (access: 27.02.2019)

[www 03] https://indiankanoon.org/doc/313445/ (access: 27.02.2019)

[www 04] https://indiankanoon.org/doc/1907607/ (access: 27.02.2019)

[www 05] https://www.legalcrystal.com/case/805706/narayana-bharatigalalias-kappiyur-swamiyar-avergal-vs-ittuli-amma (access: 27.02.2019) [www 06] http://www.sreemunchiraimutt.com/parambara/ (access: 27.02.2019) [www 07] http://www.the-laws.com/Encyclopedia/Browse/Case?CaseId= 894291653200 (access: 27.02.2019) 